\title{
A spatial assessment of the forest carbon budget for Ukraine
}

\author{
Myroslava Lesiv $^{1}$ (D) Anatoly Shvidenko ${ }^{1} \cdot$ \\ Dmitry Schepaschenko ${ }^{1,2} \cdot$ Linda See $^{1} \cdot$ Steffen Fritz $^{1}$
}

Received: 24 April 2017 / Accepted: 22 February 2018 / Published online: 16 March 2018

(C) The Author(s) 2018

\begin{abstract}
The spatial representation of forest cover and forest parameters is a prerequisite for undertaking a systems approach to the full and verified carbon accounting of forest ecosystems over large areas. This study focuses on Ukraine, which contains a diversity of bioclimatic conditions and natural landscapes found across Europe. Ukraine has a high potential to sequester carbon dioxide through afforestation and proper forest management. This paper presents a new 2010 forest map for Ukraine at a $60 \mathrm{~m}$ resolution with an accuracy of $91.6 \pm$ $0.8 \%$ (CI 0.95), which is then applied to the calculation of the carbon budget. The forest cover map and spatially distributed forest parameters were developed through the integration of remote sensing data, forest statistics, and data collected using the Geo-Wiki application, which involves visual interpretation of very high-resolution satellite imagery. The use of this map in combination with the mapping of other forest parameters had led to a decrease in the uncertainty of the forest carbon budget for Ukraine. The application of both stock-based and flux-based methods shows that Ukrainian forests have served as a net carbon sink, absorbing $11.4 \pm 1.7 \mathrm{Tg} \mathrm{C}_{\text {year }}{ }^{-1}$ in 2010 , which is around $25 \%$ less than the official values reported to the United Nations Framework Convention on Climate Change.
\end{abstract}

Keywords Forest cover $\cdot$ Carbon budget $\cdot$ Carbon sink $\cdot$ Growing stock $\cdot$ Remote sensing

\section{Introduction}

Despite recent progress in assessing carbon budgets, there is still substantial uncertainty in the estimation of the carbon budget of forest ecosystems (Pan et al. 2011; Shvidenko et al. 2010; Pan

Myroslava Lesiv lesiv@iiasa.ac.at

1 International Institute for Applied Systems Analysis, A-2361 Laxenburg, Austria

2 Bauman Moscow State Technical University, Institutskaya, 1, Mytischi, Moscow region, Russia 141005 
et al. 2011; Metsaranta et al. 2017; Le Quéré et al. 2017). In addition to the inherent uncertainties in the methods and models used for studying carbon cycling, there are other possible reasons for this uncertainty, which include the absence of forest inventories in some territories, particularly those that are not managed by state forest authorities, the lack of data for some categories of forests, obsolete data in forest inventories, and the existence of territories with rapid changes in forest cover, e.g., caused by disturbances or the encroachment of forests in abandoned agricultural land. Not every country provides comprehensive information about the area or spatial distribution of forests, in particular the distribution of tree species and their age (Schepaschenko et al. 2015), and forest inventories, more generally, lack spatial information about the forests at an appropriate resolution, which hinders the consistent application of a systems approach.

Improving knowledge about land cover and the parameters of forest ecosystems is of high importance for carrying out reliable assessments of emissions and removals from the forestry sector as well as for devising solutions to diverse ecological and forest management problems. Providing accurate data on the spatial distribution of forests represents a substantial step towards gaining a better understanding of full and verified carbon accounting as it is possible to more strictly follow the principles of systems analysis; this is why it represents one of the most promising ways to decrease uncertainties (Schepaschenko et al. 2012; Shvidenko et al. 2015). One way of achieving this is through the use of data from remote sensing. Remote sensing helps to improve carbon budget estimates in several ways, combining top-down and bottom-up approaches as follows. First, satellites (optical, radar, and LIDAR instruments) are already providing reliable estimates of important biophysical parameters of forest ecosystems such as tree canopy parameters, growing stock, above-ground biomass and net primary production (NPP). Measurements of carbon dioxide $\left(\mathrm{CO}_{2}\right)$ and methane $\left(\mathrm{CH}_{4}\right)$ concentrations in the atmosphere are used for the assessment of the spatial distribution of the land carbon fluxes of these important greenhouse gases using inverse modeling (Oda et al., this issue) based on, e.g., GOSAT (http://www.gosat.nies.go.jp/en/) or OCO-2 (http://oco.jpl.nasa.gov/). Secondly, remote sensing data are indispensable for the delineation of land cover and forests with different tree species and for deriving biometric characteristics such as forest stand height and above-ground volume. Ground information is used for the validation of remote sensing products as well as for assessing these parameters that cannot be identified using remote sensing.

Ukraine, which is the focus of this study, is unique as it is one of the largest European countries and covers a substantial portion of eastern European diversity in natural landscapes. A specific feature of Ukraine is the presence of a transition zone between forest and southern forestless steppe (the xeric belt), where ecosystems are vulnerable to environmental change. In addition, Ukraine has a high potential to sequester carbon through afforestation, since the country has greater than $3 \mathrm{M}$ ha of unproductive abandoned agricultural lands (Schierhorn et al. 2013; Smaliychuk et al. 2016), as well as via other forest management activities (Galos et al. 2013).

The carbon budget of Ukrainian forests has been previously considered in a number of publications. Initial attempts were undertaken by the United States of America sponsored Country Studies Program in the 1990s (Vasilchenko et al. 1998). Several books contain methodologies that follow the requirements of the Intergovernmental Panel on Climate Change (IPCC) (Buksha and Pasternak 2005; Buksha et al. 2008). The forest carbon cycling of some regions has also been considered in detail, e.g., in the forests of the Carpathians mountains (Bun et al. 2004), or the northeastern part of the country (Pasternak 2011). Reported results on forest carbon cycling in Ukraine at the national level (www.seia.gov.ua/seia/doccatalog/document?id=138881) have mostly been based on forest inventory data by administrative regions, which limits the possibility for assessing uncertainties. Spatially explicit information on forest cover and forest parameters derived 
from remote sensing have not been used in previous assessments of forest carbon cycling in Ukraine (Shvidenko et al., 2014) although methodologies and recommendations for the use of satellite data have been considered in detail (Buksha and Pasternak 2005) and have been used for studying forest change, illegal logging, land abandonment, and carbon sequestration in parts of Ukraine (Kuemmerle et al. 2009, 2011).

Hence the overall objective of this paper is to develop a spatially-explicit assessment of the carbon budget of Ukrainian forests, which is as accurate as possible and includes the quantification of uncertainty. The methodology is based on integrating different recently developed remote sensing products with reference data collected through the Geo-Wiki tool for interpretation of very high resolution satellite imagery. The forest inventory data for 2010 were then corrected based on the remote sensing information. The components of the carbon cycle that cannot be identified from remote sensing (e.g., woody detritus, lateral fluxes) or that require special areal approaches and additional information sources (e.g., logging, fire) were adopted from previous assessments (Shvidenko et al. 2014). The detailed description of the methodology for the assessment of the forest carbon budget is described in the next section. This is followed by the presentation of the results as spatially explicit map products, their impacts on the total carbon budget, and the values disaggregated by bioclimatic region. The results are compared with other recent estimates, and the problems associated with uncertainty are then discussed, followed by the conclusions.

\section{Methodology}

\subsection{The forests of Ukraine}

Overall Ukraine is a forest-poor country with a forest cover percentage of less than $16 \%$, which is unevenly distributed over its territory. Forests in Ukraine grow in different bioclimatic zones in the flat part of the country's territory, i.e., the forest zone (Polissya, with a forest cover percentage of $37 \%$ ), the forest steppe (29\%), and the steppe (11\%), which form the major land cover type of two mountain systems, i.e., the Carpathians (up to $50 \%$ in the mountain regions) and Crimea (with practically no forest outside of the Crimean mountains). These regions differ by species composition, age, origin, and productivity. Coniferous forests cover $42 \%$ of the total forest area, with $32 \%$ pine (Pinus silvestris L.), and 10\% spruce (Picea abies Karst.) and fir (Abies alba Mill.). Hard deciduous species cover 43\%, of which oak (Quercus robur L.) and beech (Fagus sylvatica L.) dominate with $32 \%$ of the total forest area. About $32 \%$ of forests are young stands, $44 \%$ middleaged, $13 \%$ immature, and $11 \%$ mature or overmature. On the average, the forests have a high productivity, e.g., the average growing stock over the country is $200 \mathrm{~m}^{3} \mathrm{ha}^{-1}$ (Ukrstateforestproject 2012). More than $50 \%$ of the forested area are planted forests.

Ukrainian forests (in addition to those in the mountainous regions) are substantially fragmented with an average area of the primary inventory unit (i.e., the individual forest stand or other categories of forest land) of 2-3 ha, which requires the use of very high-resolution remotely sensed data for detection.

\subsection{Methodology workflow}

We have used a range of different products derived from remote sensing to estimate the spatially explicit forest carbon budget using the steps outlined in Fig. 1: (1) a forest mask was 
developed for the year 2010, (2) the spatial distribution of the forest parameters was derived based on available information, and (3) the major components of the carbon budget of the forest ecosystems were estimated, including the uncertainty. Each of these steps is described in more detail below.

\subsection{Developing the forest mask}

To reduce the uncertainties in the calculation of the forest carbon budget, we have developed a new country-wide forest map at a resolution of $60 \mathrm{~m}$ by fusing available data derived from remote sensing with reference data (Hansen et al. 2013; Chen et al. 2014; Shimada et al. 2014a). These individual maps suffer from significant thematic errors, e.g., on Hansen's tree cover map, all the wetlands have been classified as high-percentage forests; on the JAXA (Japan Aerospace Exploration Agency) PALSAR forest mask, some villages or small towns are classified as trees; on the $30 \mathrm{~m}$ GlobeLand land cover product, small patches of forest are very often aggregated to a dominant class in a neighboring area, e.g., to agriculture. To create an improved land cover map, we used a spatial analytical method called geographically weighted regression to integrate existing maps with Geo-Wiki reference data to develop a more accurate product. Here, we define reference data to be either in-situ data or data collected by visual interpretation of very high-resolution satellite imagery. The hybrid forest map is then used for the assessment of the carbon budget of the forest ecosystems in Ukraine including uncertainty. The methodology for the creation of the hybrid map and the assessment of the forest carbon budget are described in the sections that follow.

\subsubsection{Input layers}

A number of new land cover products derived from remote sensing have recently emerged. The overall trend has been towards a higher spatial resolution such as the $30-\mathrm{m}$ resolution

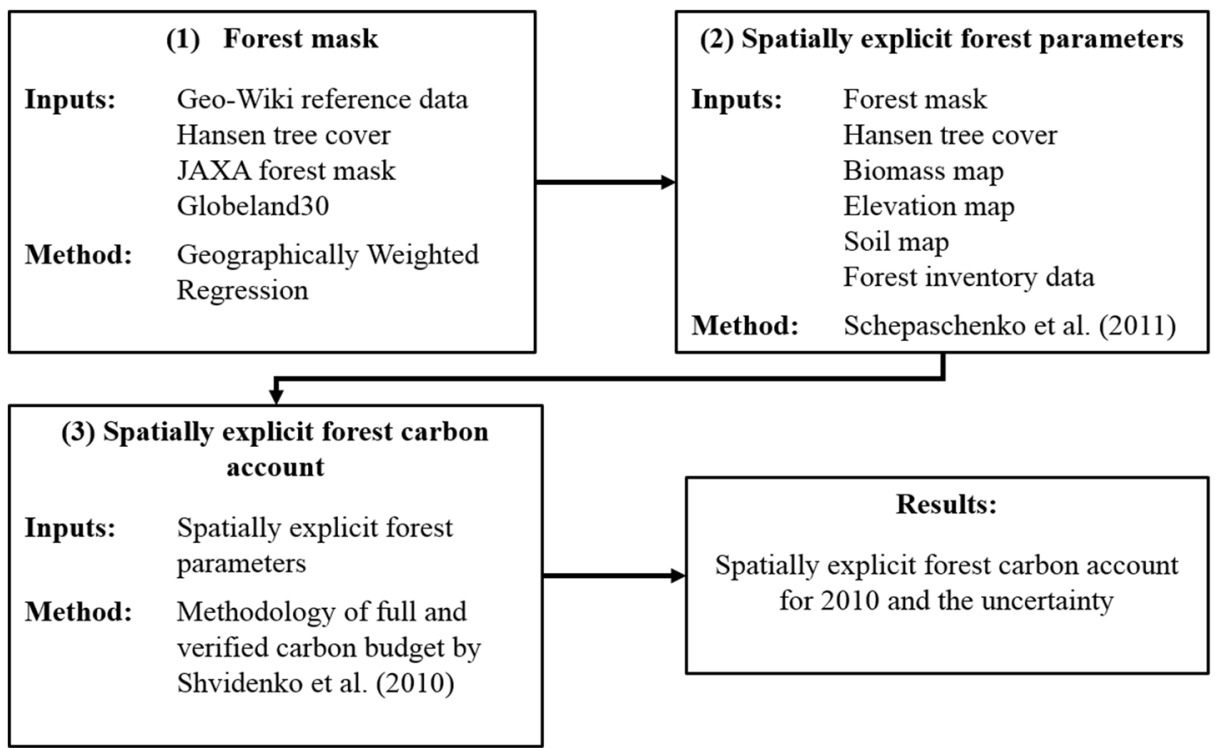

Fig. 1 Scheme for the development of a spatially explicit forest carbon budget 
maps of percentage tree cover, as well as tree cover gain and loss by Hansen et al. (2013), and the $30 \mathrm{~m}$ GlobeLand land cover product (Chen et al. 2014). These maps were developed from Landsat high-resolution satellite imagery, which has recently become freely available (Wulder et al. 2012). Another product that has become available is forest mask that has been produced by the Japan Aerospace Exploration Agency (JAXA) at a resolution of $25 \mathrm{~m}$ (Shimada et al. 2014). Other coarser resolution data sets are also available, e.g., Globcover 2009 with a resolution of $300 \mathrm{~m}$ (Bontemps et al. 2011), the MODIS Vegetation Continuous Fields product at $250 \mathrm{~m}$ (DiMiceli et al. 2011), etc. Disaggregation of the medium resolution products to a finer resolution increases the uncertainty of estimating the spatial distribution of forests. Therefore, Hansen's tree cover, GlobeLand30, and the JAXA forest mask were chosen for the development of a hybrid forest map at a resolution of $60 \mathrm{~m}$ for the year 2010 . These products are described briefly below.

The Landsat-based tree cover product is a global forest cover change product for the years 2000-2012 with a spatial resolution of $30 \mathrm{~m}$ (Hansen et al. 2013). The product has three components: forest cover 2000, forest gain 2000-2012, and annual forest loss. We created a forest map for 2010 by combining the data from these three products. Starting with the forest map for 2000 as the base year, we adjusted the map by adding forest gains and subtracting forest losses for the time period 2000-2010 to produce a forest map for 2010 .

The $30 \mathrm{~m}$ GlobeLand30 product for 2000 and 2010 has been developed by the National Geomatics Center of China (Chen et al. 2014). It is based on Landsat imagery in combination with additional information on land resources and imagery from the HJ-1 satellite. The product is freely available and comprises ten land cover classes including forest. We extracted a forest mask for Ukraine from the GlobeLand30 product for the year 2010.

JAXA has produced a 25-m forest mask based on imagery from the Phased Array type Lband Synthetic Aperture Radar (PALSAR) aboard the Advanced Land Observing Satellite "DAICHI" (ALOS) (Shimada et al. 2014).

We have only used forest cover information derived from these three maps. We aggregated these maps to a resolution of $60 \mathrm{~m}$ to minimize the spatial errors when comparing the different products, resulting in a percentage forest cover map for each product.

\subsubsection{Reference data from Geo-Wiki}

Reference data on forest cover were collected using the Geo-Wiki application (Fritz et al. 2012), which aims to validate, correct, and enhance land cover products. Five forestry and remote sensing experts collected the data by visually estimating the percentage of forest cover visible in a 60-m pixel overlaid onto very high resolution Google Earth imagery. To aid the interpreters, each $60-\mathrm{m}$ pixel was further subdivided into nine cells. Here we have defined forest as an area with a minimum tree canopy cover of $25 \%$ and a minimum area of 0.5 ha, which corresponds to the official definition of forest in Ukraine (Ukrstateforestproject 2012). This corresponds to slightly more than two cells within each 60-m pixel and a total tree canopy cover of more than $25 \%$.

Figure 2 illustrates how the forest data were collected through a customized application within Geo-Wiki. The training data samples were randomly generated in areas of forest and non-forest using a random stratified design, where the strata were based on the Hansen tree cover map. The final training data set contains approximately $12 \mathrm{~K}$ pixels of land cover information (presence/absence of forest) for Ukraine. 
The validation data have also been collected through Geo-Wiki and the data set includes approximately $4 \mathrm{~K}$ pixels. The sample has been generated by following the validation guidelines of Olofsson et al. (2014). The sample design is random stratified, where the strata are based on the resultant forest presence/absence map.

\subsubsection{Geographically weighted regression}

We have chosen geographically weighted regression (GWR) as the method to fuse the three abovementioned land cover products with the training data collected using Geo-Wiki to create a hybrid forest cover map. Lesiv et al. (2016) have shown that GWR performs better than other data fusion methods because GWR estimates the model parameters at each geographical location using a kernel. In addition, the observations are weighted by distance, so those closer to the location of interest will have more influence on the parameter estimates.

The probability of forest presence was then estimated using logistic GWR where the probabilities of correspondence between the Geo-Wiki training data and the input layers were calculated as follows:

$$
\operatorname{logit}\left(P\left(y_{i}=1\right)\right)=b_{0\left(u_{i}, v_{i}\right)}+b_{1\left(u_{i}, v_{i}\right)} x_{1(i, j)}+b_{2\left(u_{i}, v_{i}\right)} x_{1(i, j)}+\ldots+b_{n\left(u_{i}, v_{i}\right)} x_{n(i, j)},
$$

where $P\left(y_{i}=1\right)$ is the probability of forest at each location $i$; log it is a logistic regression; $\left(u_{i}\right.$, $\left.v_{i}\right)$ is the two-dimensional vector of location $i ; b_{0\left(u_{i}, v_{i}\right)}$ is the intercept; $b_{j}, j=\overline{1, n}$ are coefficients of the logistic regression model; $x_{j}, \overline{j=1, n}$ indicates the percentage of forest cover in a pixel by global land cover product $j$, and $n$ is the number of input data sets.

Maps of forest probabilities were converted to forest presence/absence maps by applying a threshold of 50\%, following the example of the usage of logistic regression models in Pampel (2000). The hybrid forest map was developed in the R environment, which is a free statistical software with various geographical libraries. The hybrid forest map was then assessed using an

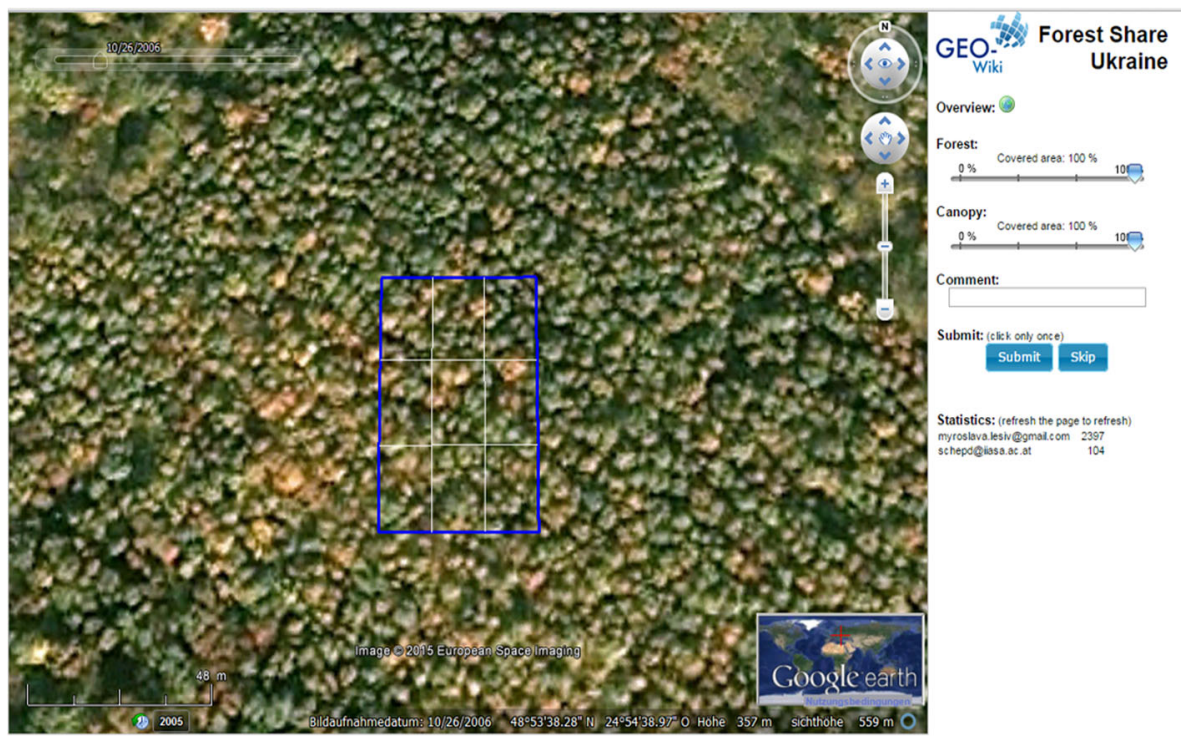

Fig. 2 A customized Geo-Wiki application for collecting forest cover reference data 
independent validation data set for Ukraine collected using Geo-Wiki as outlined previously in section 2.3.2.

\subsection{Spatially explicit forest parameters}

Forest ecosystem parameters include actual forest characteristics that are being recorded and permanently updated by the forest inventory in Ukraine. These parameters include, among others, the tree species, their age, the relative stocking, the site index, the growing stock volume, and the area in ha. These individual stand data are collected by forest enterprises, which are administrative forest units managed by the state. We have used official data for the year 2011, which is the latest available forest database.

The forest ecosystem parameter database has been downscaled to the level of the forest map developed here. For downscaling, we applied the method presented in Schepaschenko et al. (2011). We calculated a suitability index for each pixel pair (i.e., between the forest pixel and the forest inventory database record) within the territory unit (or forest enterprise). A forest pixel is a pixel of the forest map that is covered by forest. We used the following formula:

$$
\begin{gathered}
S_{\mathrm{ts}}=\frac{1}{q}\left(\sum_{j=1}^{q}\left(x_{\mathrm{t} \mathrm{norm}}^{\mathrm{nor}}-x_{\mathrm{sj}}^{\mathrm{norm}}\right)^{2}\right)^{\frac{1}{2}} \\
x_{j}^{\mathrm{norm}}=\frac{x_{j}-x_{j, \min }}{x_{j, \max }-x_{j, \min }}
\end{gathered}
$$

where $S_{\mathrm{ts}}$ is the suitability index; $t$ is the forest pixel; $s$ is the record from the forest database; $q$ is the number of parameters; and $x_{j, \max }, x_{j, \min }$ are the maximum and minimum values of parameter $j$ within a certain area (i.e., the forest enterprise).

To calculate the suitability indices, we used diverse sources of information as parameters, including estimates from leading experts in forestry, who have experience of Ukrainian forests, to derive the decision rules regarding the following:

- The ecological pattern of tree species distributions in mountainous regions based on their preferred elevation and aspect

- The site index associations with slope and altitude

- The distribution of tree species depending on soil type

As explanatory layers, we used the following remote sensing products:

- The Hansen percentage tree cover map for 2010 (Hansen et al. 2013), created from the available layers as described previously, to link tree cover to the relative stocking from the forest inventory records

- A soil map of Ukraine (Krupsky and Polupan 1979), to link soil types to tree species from the database, as certain tree species prefer a certain soil type

- A biomass map (Gallaun et al. 2010) to calculate the growing stock volume

- A digital elevation model from SRTM (Shuttle Radar Topography Mission) (Werner 2001) since the distribution of tree species in mountains is very well correlated with elevation

The resultant suitability index varies from 0 to 1 . It can be interpreted as the distance between objects (i.e., the forest pixel and the database record) within the space of parameters. The lower the value of the index, the more suitable is the current piece of territory. Each forest record in the database was assigned to the most suitable pixel within each forest enterprise. 


\subsection{Estimating the parameters of the forest carbon budget}

For assessment of the carbon budget of Ukrainian forests, a methodology for a full and verified carbon budget was used, which was developed by the International Institute for Applied Systems Analysis (Shvidenko et al. 2015). The methodology is based on a system combination of flux-based and stock-based methods. The stock-based method estimates the change in the carbon stock of carbon pools as

$$
\Delta C=\Delta \mathrm{LB}+\Delta \mathrm{WD}+\Delta S
$$

where $\Delta \mathrm{LB}, \Delta \mathrm{WD}$ and $\Delta S$ are changes in the carbon stocks of live biomass, woody detritus, and soil, respectively, while the flux-based method has the following form:

$$
\mathrm{NBP}=\mathrm{NPP}-\mathrm{HSR}-\mathrm{DEC}-\mathrm{HARV}-\mathrm{DIST}-\mathrm{LAT}
$$

where NBP is net biome production; NPP is net primary production; HSR is heterotrophic soil respiration; DEC is the flux due to decomposition of dead wood that remains in the forest; HARV are the fluxes due to harvest and international trade of wood products; DIST is the flux caused by disturbances, and LAT are lateral fluxes to the hydrosphere and lithosphere. Both of these methods have strengths and weaknesses (e.g., Shvidenko et al., 2010, 2015). For example, the dynamics and variability of soil carbon content do not allow for the reliable monitoring of soil carbon changes in the stock-based method, while the NPP flux can be estimated much more accurately using the biomass change approach. This is why we have used both methods together in a complimentary way.

Live biomass (LB) was defined using a multi-dimensional regression of biomass expansion factors $\left(R_{\mathrm{fr}}\right)$ by species, geographical regions (where relevant), and LB components (Shvidenko et al. 2007) as follows:

$$
R_{\mathrm{f} r}={ }^{M}{ }_{\mathrm{fr}} / \mathrm{GS}=a_{0} \times A^{a_{1}} \times \mathrm{SI}^{a_{2}} \times \mathrm{RS}^{a_{3}} \times \operatorname{EXP}\left(a_{4} \times A+a_{5} \times \mathrm{RS}\right)
$$

where $R_{\mathrm{fr}}$ is the ratio of the mass of individual components of LB (stem wood over bark; crown wood; foliage; roots) to growing stock volume; $M_{\mathrm{fr}}$ is the mass of individual components of $\mathrm{LB}$, dry matter or carbon units, $t \mathrm{ha}^{-1}$; GS is the growing stock volume, $\mathrm{m}^{3} \mathrm{ha}^{-1} ; A$ is the average age of stands in years; $\mathrm{SI}$ is the site index; RS is the relative stocking, and $a_{1}, a_{2}, \ldots a_{5}$ are the regression coefficients. The mass of LB is then defined as $\mathrm{LB}_{\mathrm{fr}}=R_{\mathrm{fr}} \times \mathrm{GS}$ and $\mathrm{LB}_{\text {tot }}=\Sigma \times \mathrm{LB}_{\text {fr }}$, where $\mathrm{LB}_{\text {tot }}$ is the total LB of an individual forest ecosystem. Equation (6) is based on extensive field experiments (using destructive sampling) collected in a database that includes more than 11,000 sample plots for temperate and boreal forests (Schepaschenko et al. 2017b). When Eq. (6) is applied to multiple species, there is no systematic error. Moreover, such an approach can estimate LB within a $15 \%$ error band (CI 0.9) for an individual forest stand if the GS is defined within the officially required maximum error of 12\% (Shvidenko et al. 2014). The yearly change in the LB stock (i.e., current increment by LB) was defined as the difference between the LB of two consecutive years.

The last two components of Eq. (4) cannot be measured by remote sensing directly. The change in the woody detritus stock was recalculated based on forest area change, forest inventory data, and a database of direct in situ measurements; this stock included dry standing trees (snags), dry branches of living trees, logs, and stumps. These data were calculated for 2000-2010. Taking into account the substantial uncertainty in the input data, the calculation was done at the level of administrative regions. Satisfactory data on the dynamics of soil 
carbon in Ukrainian forests are absent. We used the average data published for European forests (Kramer and Mohren 2001; Mund and Schulze 2006; Kutsch et al. 2010) for corresponding tree species in similar climate conditions to Ukraine, which were in line with the limited data available for Ukraine (Pasternak 2011).

NPP was defined by a semi-empirical method described in Shvidenko et al. (2007). It is calculated based on regionally distributed models of biological productivity, which combine models of growth and LB dynamics. Within this method, NPP is considered to be the difference in total productivity of LB for two consecutive years, taking into account the turnover of fine roots and foliage, damage by wind, insects, harvest, etc. This method does not have any recognized biases compared to a direct aggregation of results from field measurements, which do not account for some important components of carbon turnover (e.g., root exudates, volatile organic compounds). The uncertainty in the NPP was defined in an independent way, i.e., through a correlation between the current increment of LB and NPP.

Heterotrophic soil respiration (HSR) was calculated using the approach presented in Mukhortova et al. (2015) by groups of soil types $i$ and dominant tree species $j$ as

$$
\operatorname{HSR}(i, j)=\operatorname{TSR}(i) \cdots \operatorname{PHSR}(i, j) \cdots A(i, j) .
$$

where TSR is total soil respiration; PHSR is the percentage of HSR in TSR, and $A$ is the area of the dominant species.

DEC was assessed based on zonal coefficients of decomposition that were averaged based on measurements in Ukrainian forests and regions of similar climatic conditions and forest types of the Eurasian temperate zone. The amount of harvested wood, as well as data on natural disturbances, were taken from the official statistics of the State Agency of Forest Management of Ukraine. Natural disturbances included fire, impacts of insects and diseases, and the impact of unfavorable weather conditions. Carbon fluxes caused by forest fire were assessed by an approach presented in Shvidenko et al. (2014). The assessment of the impacts of biogenic factors and unfavorable weather conditions on productivity and the health status of forests was based on an estimation of the forest-pathological state of Ukrainian forests by administrative region for previous years and forecast to 2020 (Ustsky et al. 2010; Ustsky 2011). The forest-pathological state was quantified using the percentage of mortality for six levels of severity due to forest-pathological processes.

Spatially-explicit regional estimates of the removal of carbon in the hydro- and lithosphere in Ukraine are absent. We used published data for the temperate forests of the Northern hemisphere, which provide average values in the range of 1.5-2\% of NPP (e.g., Dolman et al. 2012).

The stock- and flux-based methods were used to produce independent estimates of the carbon cycle of Ukraine's forests. The uncertainties in these methods were calculated based on the application of error propagation theory: for a function $y=f\left(x_{1}, x_{2}, \ldots, x_{k}\right)$, where $x_{i}(i=1, \ldots$, $k$ ) are stochastic variables with standard errors $m_{i}$, the standard error of $y$ is defined as

$$
m_{y}^{2}=\sum_{i=1}^{k}\left(\frac{d y}{d x_{i}}\right)^{2}+2 \sum_{i>j}\left(\frac{d y}{d x_{i}}\right)\left(\frac{d y}{d x_{i}}\right) r_{i j} m_{x_{i}} m_{x_{j}}
$$

where $r_{\mathrm{ij}}$ is the correlation coefficient between $x_{i}$ and $x_{j}$, and dy/dx $x_{i}$ are the partial derivatives of $y$ by $x_{i}$.

When $r_{\mathrm{ij}}<0.2-0.3$, which is typical for the majority of the estimated parameters, the use of only the first component of the right part of Eq. (8) does not change the level of the final 
uncertainty substantially; thus, in appropriate cases, we used Eq. (8) in a simplified form, i.e., assuming statistical independence of the input variables.

A specific feature of the carbon accounting and estimation of uncertainties that are presented in this paper is the use of a forest inventory database for forests in Ukraine. This database contains biometric characteristics of ca $3.6 \times 10^{6}$ individual stands, i.e., primary inventory units, from about $2 \times 10^{3}$ for larch to over $10^{6}$ for oak stands. This has had an impact on the specifics and size of the uncertainties because it has practically eliminated the sampling error in some cases. We have provided calculations of these parameters for forests with the ten major dominant species, which cover about $95 \%$ of the forest area in Ukraine. In the calculations, the relevant data about the rest of the tree species that cover the remaining area were added to the species with similar bioecological properties.

\section{Results}

\subsection{A hybrid forest map and forest parameters for Ukraine}

The first output in this study is the hybrid forest map for the year 2010 for Ukraine and the forest ecosystem parameters. These are required as inputs for the calculation of the spatially explicit carbon budget. The hybrid map represents the first forest map for this country at a 60$\mathrm{m}$ resolution. The overall accuracy of the map is $91.6 \pm 0.8 \%$ (CI 95\%). Table 1 presents a summary of the accuracy estimates of the new forest mask and the input maps used in its development. The differences in the accuracy estimates between each possible pair of maps are statistically significant ( $p$ values < 0.01) (Foody 2004).

Bilous et al. (2017) estimated the accuracy of several forest maps for $45 \mathrm{~km}^{2}$ of the Snovsk test area in the Ukrainian Polissya region. They have shown that our hybrid map performs the best (user's accuracy 92\%, producer's accuracy 81\%) compared to other global data sets presented in this study.

The total area of forest was calculated to be $8.7 \pm 0.2 \mathrm{M}$ ha (CI 95\%) while the official statistics report 9.6 M ha of forested area in Ukraine (Ukrstateforestproject 2012). There are different potential reasons for this inconsistency. Electronic maps and databases are only available for $8.5 \mathrm{M}$ ha in Ukraine. The rest is represented by forests that are not managed $(7.5 \%)$ and another $6 \%$ that belong to more than 30 different "non-forest" stakeholders (such as the Ministry of Defense and different administrative bodies) with a low or practically absent forest management. The last inventories of these forests were dated around the 1990s, and their real state may be substantially different from the inventory records. In addition, official Ukrainian statistics do not take forested areas on abandoned agricultural land of ca $3 \mathrm{M}$ ha into account, which are largely in the forest steppe and steppe regions. The process of the impoverishment of forests in the southern forest steppe and steppe, particularly of protective

Table 1 Overall accuracy estimates of the final hybrid forest map and the input forest maps

\begin{tabular}{llr}
\hline Maps & Overall accuracy $\%$ & $P$ values \\
\hline Hybrid forest map & 91.6 & $<0.01$ \\
GlobeLand 30 m & 88.0 & $<0.01$ \\
Hansen's forest map & 86.7 & $<0.01$ \\
JAXA's PALSAR forest map & 84.7 & $<0.01$ \\
\hline
\end{tabular}


forests and shelterbelts on agricultural land, has been repeatedly reported (Fourdichko et al. 2006). The new map reports forested areas for the southern administrative regions (oblasts) that are substantially less than the corresponding forest inventory data, i.e., up to $30 \%$ less, while the regions with forest zones (i.e., Polissya and Carpathians) have similar areas on the map when compared with the forest statistics; sometimes more areas are recorded than in the forest inventory. Indeed, the remote sensing products used in the production of the input forest maps may not recognize narrow shelterbelts in the south, young forests, substantially degraded forests, and afforestation of abandoned agricultural land. Issues associated with mapping of dryland forests are also discussed in Schepaschenko et al. (2017a). Therefore, the mapped forest area is smaller than the forest area estimate. However, the area of such forests is small, i.e., several percent by region. In addition, the new forest map might consider other tree covered areas (e.g., gardens, parks in settlements, etc.) as forests if their canopy cover exceeds the minimum threshold.

From the forest map, we have developed the following spatially explicit forest ecosystem parameter maps: the spatial distribution of tree species, the spatial distribution of total biomass, and the spatial distribution of NPP. The spatially explicit map of dominant tree species (Fig. 3) is the first tree species map at such a fine resolution and with such a detailed nomenclature, fully covering Ukraine. It shows a good spatial distribution of tree species in the mountainous regions of Ukraine, in particular, for beech and spruce trees. However, the spatial distribution of tree species on flat areas has some noise. This map (Fig. 3) also captures dominant tree species by forest enterprises very well.

The accuracy of our tree species map for the Snovsk test area (Bilous et al. 2017) was estimated as $71 \%$, while the overall accuracy of the European tree species data set (Brus et al. 2012) was only $36 \%$ for the same area. Our growing stock volume estimation was again the most reliable when compared to any other global or regional data sets (Bilous et al. 2017).

Figure 4 highlights the forest areas with the highest biomass values such as the Carpathians, and with the lowest biomass, i.e., the Volyn region in Ukraine in the northern and southern regions.

Figure 5 shows the spatial variation of NPP of Ukrainian forests. The patterns are very similar to the spatially explicit forest biomass map (Fig. 4).

\subsection{The forest carbon budget and its uncertainties}

Using the hybrid forest map and the methodology outlined in Section 2.3, the results of the assessment of the LB of Ukraine's forests, as a crucial component of the stock-based method, is presented in Table 1. LB is aggregated by dominant species and for the country as a whole. The LB stock is assessed at 707.7 $\mathrm{Tg} \mathrm{C}$, or $81.2 \mathrm{t} \mathrm{C} \mathrm{ha}^{-1}$. Trees comprise $95 \%$ of carbon of the total LB; $82 \%$ are in above-ground LB; $68 \%$ are in stem wood, and $17 \%$ are in roots. Only $5 \%$ of the carbon in forest ecosystems are in the understory and the green forest floor. Overall, such proportions are typical for temperate forests of high productivity.

The calculated uncertainty in total LB includes errors in the regressions of the biomass expansion factors, the growing stock volume, and the area (Table 2). If LB is expressed in units of dry matter, the final error is estimated at $\pm 3.3 \%$. If the error from the recalculation of the LB in carbon units is added, where we used an additional error of $\pm 1.5 \%$ in this estimation, then the final error is $\pm 3.6 \%$. Here and below these estimates are to one standard error unless otherwise stated. Because the LB was calculated for each forest stand in the database, the 


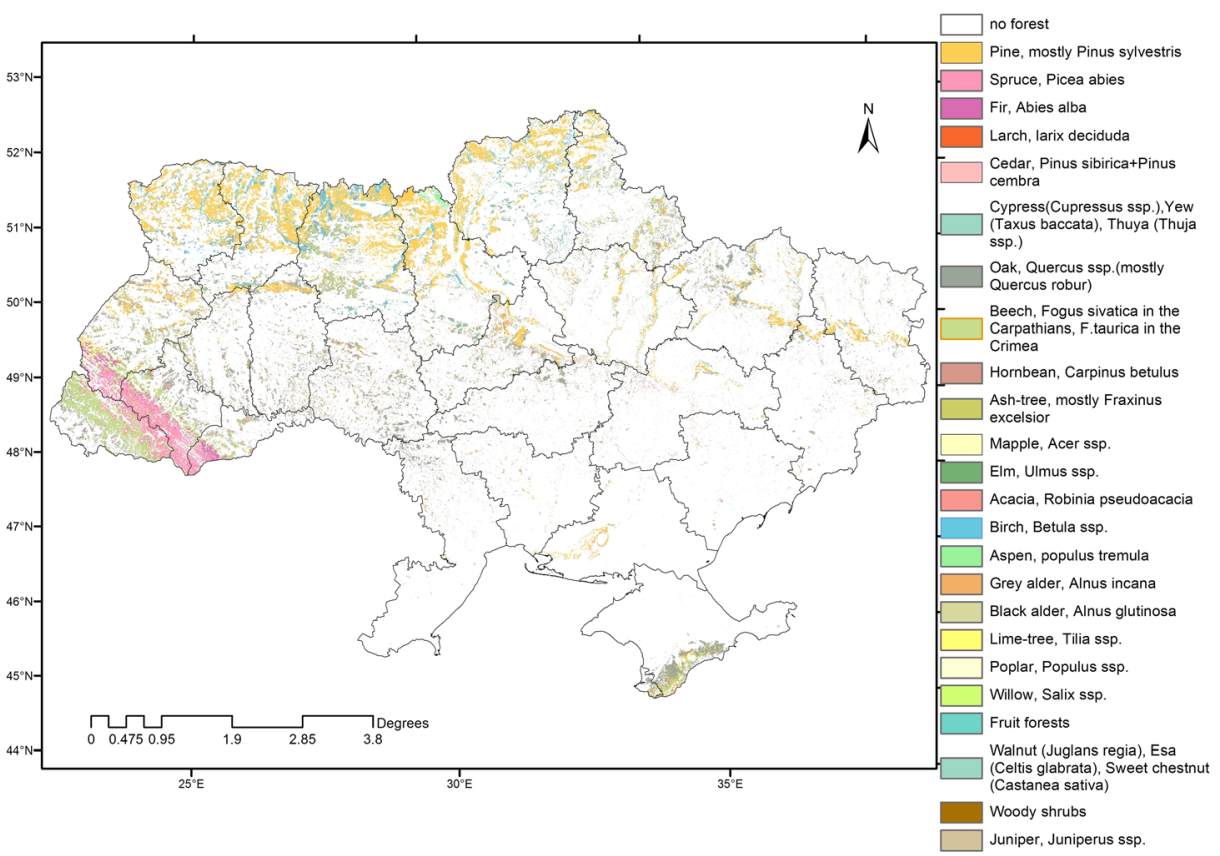

Fig. 3 The spatial distribution of dominant tree species for 2010

impact of the uncertainties of the biomass expansion factor regressions on the uncertainties of the average values of LB by tree species was very small.

The total volume of woody detritus is estimated at $141.3 \mathrm{M} \mathrm{m}^{3}$ (including $56 \%$ in dead trees and snags and $44 \%$ in logs). Using an average specific gravity of 0.35 for snags and

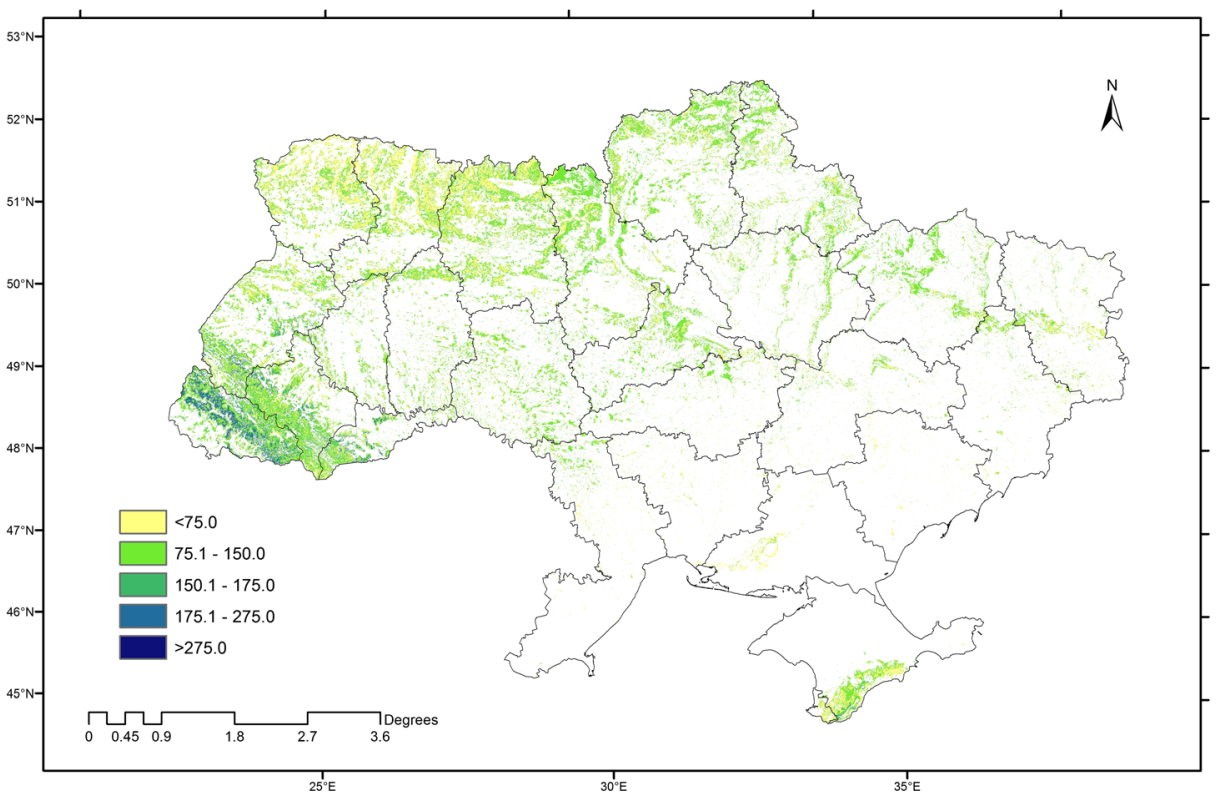

Fig. 4 Biomass map for 2010, $\mathrm{t} \mathrm{C} \mathrm{ha}^{-1}$ 


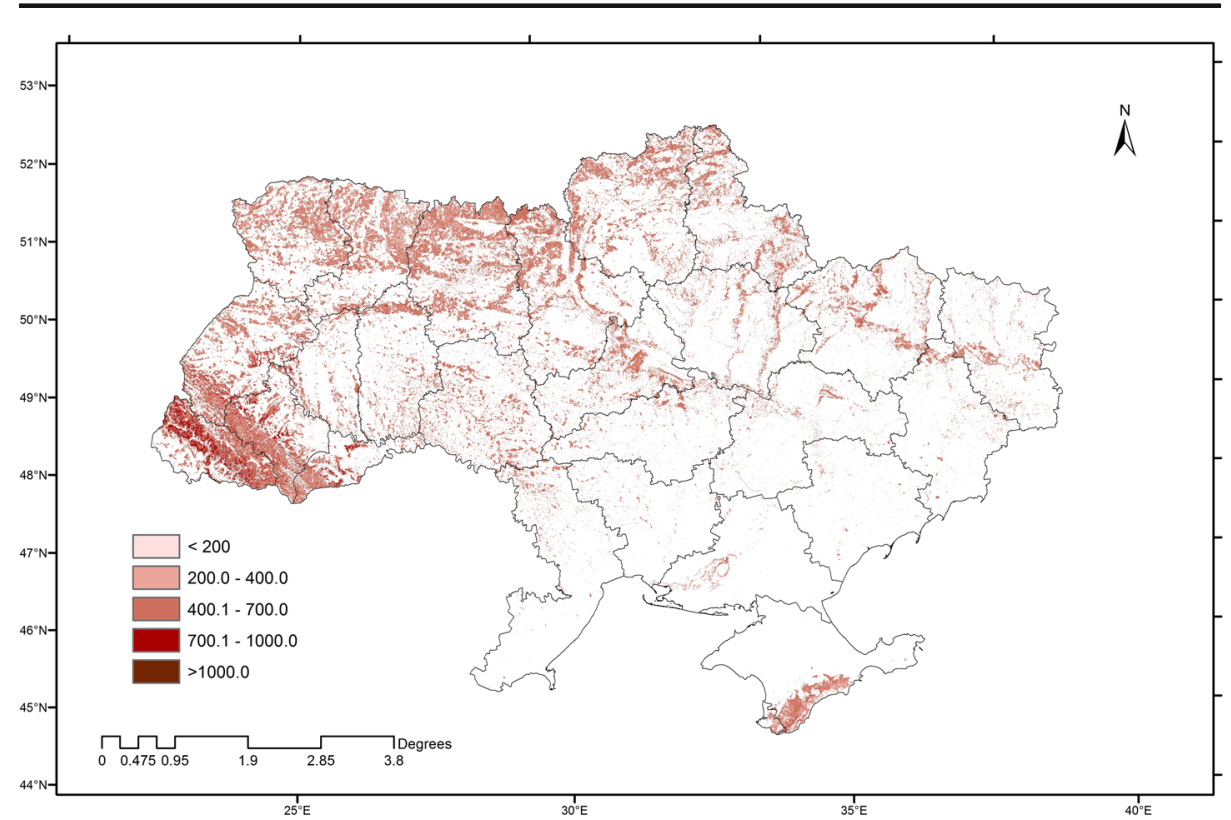

Fig. 5 Net primary production (NPP) of Ukrainian forests for 2010, $\mathrm{g} \mathrm{C} \mathrm{m}^{-2}$ year $^{-1}$

$0.25 \mathrm{Mg} \mathrm{d} . \mathrm{m} . \mathrm{m}^{-3}$ for logs plus an assumption of $50 \%$ carbon content in the dry matter, then the carbon stock in woody detritus can be estimated at $21.7 \mathrm{Tg} \mathrm{C}$, or $3.1 \%$ of the total stock of carbon in LB. Reliable estimates of woody detritus dynamics are possible only based on a long period of observation. Assuming that the share of woody detritus to the total LB does not change over a short period (i.e., 2 to 3 years), the stock change in the woody detritus will increase to $1.56 \mathrm{Tg} \mathrm{C}$ year $^{-1}$ (which is $3.1 \%$ of the LB annual increment; see Table 3 ). Assuming that the standard error of this change is $20 \%$, we obtain a sink in dead aboveground wood of $1.56 \pm 0.32 \mathrm{Tg} \mathrm{C}$ year $^{-1}$.

Despite a number of publications on the impacts of forests on soil carbon under afforestation in Ukraine, there are no systematic inventories of the dynamics of soil carbon in forests that have not undergone large scale disturbances. The official reporting of Ukraine to the

Table 2 Total LB of Ukrainian forest by dominant species

\begin{tabular}{lrrrrrr}
\hline Species & Area, $10^{3}$ ha & GS, $10^{6} \mathrm{~m}^{3}$ & $R_{\text {tot }}$ & $m_{R \text { tot }}$ & LB, Tg C & $m_{\text {LB }}$, Tg C \\
\hline Pine & 3049.0 & 721.7 & 0.6268 & 0.0215 & 226.2 & 8.54 \\
Spruce & 662.0 & 209.4 & 0.6570 & 0.0204 & 68.6 & 2.35 \\
Fir & 133.5 & 35.8 & 0.6081 & 0.0204 & 10.9 & 0.41 \\
Larch & 9.4 & 2.1 & 0.7033 & 0.0235 & 0.7 & 0.03 \\
Oak & 2515.3 & 422.4 & 0.9623 & 0.0307 & 203.2 & 7.13 \\
Beech & 759.1 & 232.6 & 0.9699 & 0.0317 & 112.8 & 4.06 \\
Acacia & 203.5 & 13.9 & 1.2757 & 0.0389 & 8.8 & 0.30 \\
Birch & 690.1 & 97.0 & 0.8097 & 0.0264 & 39.3 & 1.41 \\
Aspen & 158.8 & 25.1 & 0.7620 & 0.0234 & 9.6 & 0.33 \\
Alder & 531.7 & 82.9 & 0.6602 & 0.0224 & 27.4 & 1.03 \\
Total & 8712.5 & 1842.9 & & & 707.7 & 25.62 \\
\hline
\end{tabular}

$G S$, growing stock volume; $R_{\text {tot }}$, biomass expansion factor for the total ecosystems LB $\left(R_{\text {tot }}=R_{\text {stem }}+R_{\text {branches }}+\right.$ $\left.R_{\text {foliage }}+R_{\text {roots }}+R_{\text {understory }}+R_{\mathrm{gff}}\right) ; L B$, live biomass; $m$, standard error 


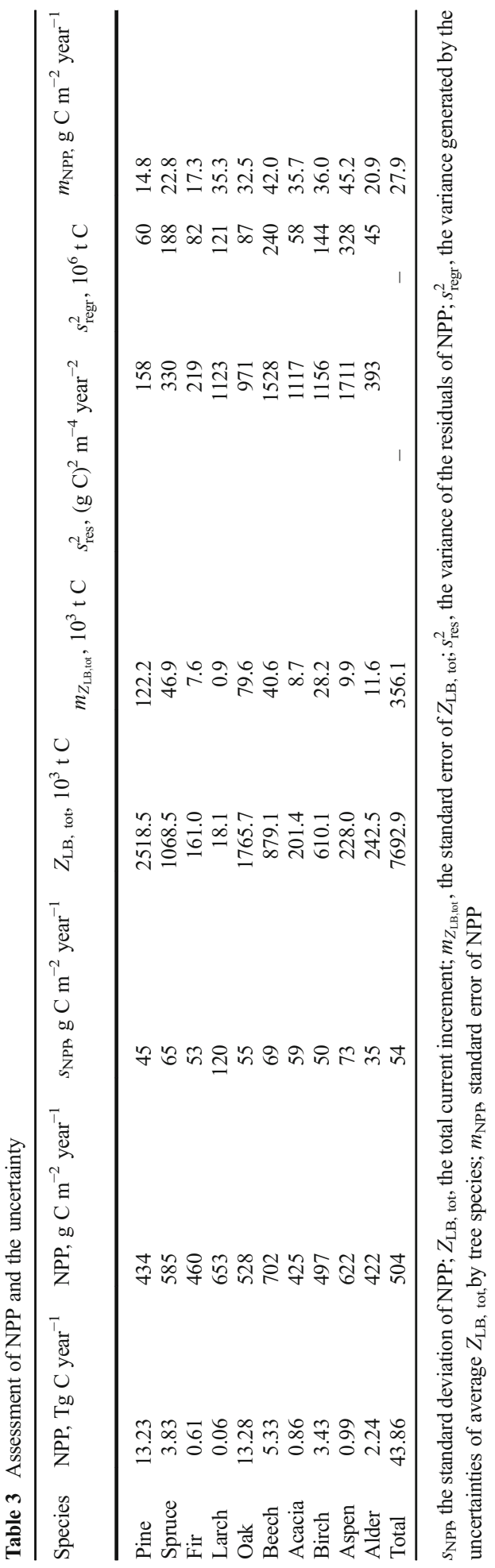


Table 4 Assessment of heterotrophic soil respiration and its uncertainty

\begin{tabular}{|c|c|c|c|c|c|c|c|c|c|}
\hline Soil groups & $\begin{array}{l}\text { Area } \\
10^{3} \text { ha }\end{array}$ & $m_{\text {area }}$ & $\begin{array}{l}\text { TSR } \\
\mathrm{g} \mathrm{C} \mathrm{m}^{-2}\end{array}$ & $\begin{array}{l}m_{\mathrm{TSR}} \\
\text { year }^{-1}\end{array}$ & $\begin{array}{l}\text { HSR } \\
\%\end{array}$ & $m_{\mathrm{HSR}}$ & $\begin{array}{l}\text { HSR } \\
\text { average } \\
\mathrm{g} \mathrm{C} \mathrm{m}^{-2}\end{array}$ & $\begin{array}{r}m_{\mathrm{HSR}} \\
\text { year }^{-1}\end{array}$ & $\begin{array}{l}\text { HSR } \\
\text { Tg C year }\end{array}$ \\
\hline Luvisols and Greyzems & 2421.3 & 99.3 & 569 & 18.6 & 48.7 & 1.2 & 277 & 16.0 & 6.71 \\
\hline Gleysols & 974.9 & 40.0 & 619 & 47.9 & 49.1 & 1.8 & 304 & 28.9 & 2.96 \\
\hline Histosols & 646.6 & 26.5 & 525 & 20.5 & 48.8 & 1.8 & 256 & 17.3 & 1.66 \\
\hline $\begin{array}{l}\text { Cambisols and Metamorphic } \\
\text { soils }\end{array}$ & 1361.8 & 55.8 & 645 & 26.7 & 49.9 & 1.2 & 322 & 20.3 & 4.38 \\
\hline $\begin{array}{l}\text { Phaeozems, Histosols and } \\
\text { Leptosols }\end{array}$ & 722.4 & 29.6 & 1103 & 65.4 & 48.2 & 1.8 & 532 & 43.2 & 3.84 \\
\hline $\begin{array}{c}\text { Chernozems and } \\
\text { Kastanozems }\end{array}$ & 2111.1 & 86.6 & 538 & 34.3 & 47.6 & 1.8 & 256 & 21.7 & 5.40 \\
\hline Fluvisols & 206.4 & 8.5 & 1140 & 41.8 & 48.2 & 1.8 & 550 & 36.6 & 1.14 \\
\hline Calcisols and Solonetz & 215.7 & 8.8 & 434 & 21 & 46.7 & 1.8 & 203 & 15.1 & 0.44 \\
\hline Leptosols & 52.3 & 2.1 & 666 & 34.3 & 39.8 & 1.2 & 265 & 19.2 & 0.14 \\
\hline Total & 8712.5 & 357.2 & - & - & - & - & 306 & 23.7 & 26.67 \\
\hline
\end{tabular}

$H S R$, heterotrophic soil respiration; TSR, total soil respiration; $m$, standard error for different variables in the table

Secretariat of the UNFCCC uses an assumption that soil carbon stock does not change in those forests that remain forests for the period of the assessment (www.seia.gov. ua/seia/doccatalog/document?id=138881). However, in-situ measurements do not corroborate this. The modeling calculations for European forests show that approximately $70 \%$ of carbon inputs are accumulated in LB and woody detritus and 30\% in soil including litter (Liski et al. 2002; Nabuurs et al. 2003). Other studies estimate the accumulation of carbon in the soil of forest ecosystems to be in the range of 10-50 $\mathrm{g} \mathrm{C} \mathrm{m}^{-2}$ year $^{-1}$ (Mund and Schulze 2006; Kutsch et al. 2010). According to Kramer and Mohren (2001), while the net annual accumulation of carbon in the soil of European forests is $0.05 \mathrm{~kg} \mathrm{C} \mathrm{m}^{-2}$ year $^{-1}$. The first approach yields 2.3 $\mathrm{Tg} \mathrm{C}$ year ${ }^{-1}$, while the second produces estimates that range from 0.9 to 4.4 , or on average 2.6 $\operatorname{Tg~C}$ year $^{-1}$. Taking into account the specifics of Ukrainian forests (i.e., harvested and fire areas, use of woody detritus for fuel, and area of planted forests), we have used a conservative estimate of $75 \%$ of the average of the above two approaches (1.88 $\left.\mathrm{Tg} \mathrm{C} \mathrm{year}^{-1}\right)$. Assuming an error of $50 \%$, we would obtain an annual input to the woody detritus pool of $1.88 \pm 0.94$ $\mathrm{Tg} \mathrm{C}$ year $^{-1}$. Following Eqs. (1) and (4), the net ecosystem carbon budget (NECB) of Ukrainian forests is estimated by the stock-based method to be $11.1 \pm 1.4 \mathrm{Tg} \mathrm{C}_{\text {year }}{ }^{-1}$, which is an error of $12.6 \%$.

With respect to the flux-based method, we estimated two major fluxes: NPP (Table 3) and HSR (Table 4). Similarly to LB, NPP was defined for each individual stand. The total NPP was determined to be $44.0 \mathrm{Tg} \mathrm{C}$ year $^{-1}$, i.e., the average for Ukraine is $504 \pm 28 \mathrm{~g} \mathrm{C} \mathrm{m}^{-2}$ year $^{-1}$ (with an error of $\pm 5.6 \%$ ). The spatial variability of NPP is high (Fig. 5). The uncertainty in NPP was estimated in an independent way, based on regressions between the average increment of LB and NPP by dominant tree species. The current increment of total LB was calculated as the difference in the total stock of LB by individual stands with an aggregation by dominant species for two consecutive years and was estimated to be $7.69 \mathrm{Tg} \mathrm{C}_{\text {year }}{ }^{-1}$. The regressions were calculated separately for coniferous species as follows:

$$
y=1931 \cdot \mathrm{x}+2488, \mathrm{R}^{2}=0.92, \mathrm{RMSE}=15
$$


and for deciduous species as:

$$
y=2920 \cdot \mathrm{x}+2694, \mathrm{R}^{2}=0.68, \mathrm{RMSE}=55
$$

where $x$ is the yearly increment by total LB by individual species ( $\mathrm{t} \mathrm{C}$ yearr ${ }^{-1}$ ), and $y$ is the average NPP by species. The uncertainty in the NPP was calculated by summing the variance of the increment using Eq. (8) and the regression Eqs. (9-10). The variance of the residuals was estimated as $s_{\text {res }}^{2}=s_{\text {tot }}^{2}\left(1-R^{2}\right)$.

The means and standard errors of soil respiration (SR) were calculated based on a database of SR measurements. The estimate was calculated as $26.7 \mathrm{Tg} \mathrm{C}_{\mathrm{Cear}}{ }^{-1}$, or $306 \mathrm{~g} \mathrm{C} \mathrm{m}^{-2}$ year $^{-1}$. According to Eqs. (5) and (7), the uncertainty was calculated using the variance of TSR, the share of HSR in the total soil efflux, and the area covered by the dominant species. Finally, the uncertainty of SHR was estimated to be $7.7 \%$, i.e., $306 \pm 24 \mathrm{~g} \mathrm{C} \mathrm{m}^{-2}$ year $^{-1}$, or $26.7 \pm$ $2.1 \mathrm{Tg} \mathrm{C}$ year $^{-1}$. SHR comprises $\sim 60 \%$ of NPP, and the ratio between NBP and NPP is 0.21 . The rather high uncertainties in HSR follow from the lack of knowledge about soil processes in Ukrainian forests and the absence of systematic and detailed information on soils. The database on SR only contained a few measurements made in Ukrainian forests; the scale of the available soil map was coarse (i.e., 1:2.5 M), and the relevant soil horizon indicators were weakly quantified.

The results of the total carbon budget for forest ecosystems in Ukraine estimated by the flux-based method and using the hybrid forest map is presented in Table 5.

The fluxes in Tables 3 to 5 that have not been derived from remote sensing have been adapted from a previous assessment (Shvidenko et al., 2014) and recalculated with respect to the areas of the hybrid map.

The uncertainty in these relatively small fluxes are as follows: DEC $\pm 20 \%, \mathrm{HARV} \pm 15 \%$, $\mathrm{DIST} \pm 33 \%$, and LAT $\pm 57 \%$ (where all values are rounded to integer numbers). Together this results in a final uncertainty in the yearly value of NBP defined by the flux-based method as $11.8 \pm 3.2 \mathrm{Tg} \mathrm{C}$ year $^{-1}$, i.e., the relative error is ca $28 \%$, which to a substantial extent is explained by the high annual variability in the two major fluxes (NPP and HSR) and insufficient soil information in particular. Much more accurate results from the flux-based method will be produced if longer time periods are used, e.g., $12-15 \%$ for a 5 -year period, assuming that the assessment does not have uncontrolled biases.

Table 5 Carbon budget of Ukrainian forests based on the flux-based method

\begin{tabular}{|c|c|c|c|c|c|c|c|c|}
\hline \multirow[t]{2}{*}{ Bioclimatic region } & \multirow[t]{2}{*}{ Area,K ha } & \multicolumn{7}{|c|}{ Carbon fluxes, $\mathrm{g} \mathrm{C} \mathrm{m}^{-2}$ year $^{-1}$, the totals in $\mathrm{Tg} \mathrm{C}$ year $^{-1}$} \\
\hline & & NPP & HSR & DEC & HARV & DIST & LAT & NBP \\
\hline Polissya & 3554.4 & 453 & 327 & 11 & 34 & 21 & 5 & 55 \\
\hline Forest steppe & 2562.1 & 531 & 283 & 7 & 23 & 17 & 8 & 193 \\
\hline Steppe & 608.9 & 487 & 263 & 3 & 3 & 26 & 5 & 187 \\
\hline Carpathians & 1727.3 & 589 & 325 & 14 & 32 & 9 & 12 & 197 \\
\hline Crimea & 259.9 & 442 & 273 & 6 & 2 & 12 & 6 & 143 \\
\hline Total & 8712.5 & 44.0 & 26.7 & 0.9 & 2.4 & 1.5 & 0.6 & 11.8 \\
\hline Average, $\mathrm{g} \mathrm{C} \mathrm{m}^{-2}$ year $^{-1}$ & - & 504 & 306 & 10 & 27 & 18 & 7 & 135 \\
\hline Uncertainty, $\mathrm{g} \mathrm{C} \mathrm{m}^{-2}$ year $^{-1}$ & - & \pm 28 & \pm 24 & \pm 2 & \pm 4 & \pm 6 & \pm 4 & \pm 38 \\
\hline
\end{tabular}

$N P P$, net primary production; $H S R$ heterotrophic soil respiration; $D E C$, the flux due to decomposition due to dead wood that remains in the forest; HARV, the flux due to harvest and international trade; DIST, the flux caused by disturbances; $L A T$, lateral fluxes to the hydrosphere and lithosphere; $N B P$, net biome production 
Overall, the two approaches lead to the conclusion that Ukrainian forests serve as a net carbon sink in the range from $11.0 \pm 1.4$ (stock-based method) to $11.8 \pm 3.2 \mathrm{Tg} \mathrm{C}$ year $^{-1}$ (flux-based method), or on average $11.4 \pm 1.7 \mathrm{Tg} \mathrm{C}$ year $^{-1}$ (or $131 \pm 20 \mathrm{~g} \mathrm{C} \mathrm{m}^{-2}$ year $^{-1}$ ). The sink differs by bioclimatic zone, i.e., from $55 \mathrm{~g} \mathrm{C} \mathrm{m}^{-2}$ year $^{-1}$ in Polissya to $197 \mathrm{~g} \mathrm{C} \mathrm{m}^{-2}$ year $^{-1}$ in the Carpathians. This diversity is explained by climatic and forest type drivers as well as by the intensity of the harvest and the extent and severity of natural disturbances.

\section{Discussion}

One of the key results from this study is the fact that the current forest inventory system in Ukraine does not correctly reflect areas of national forest, which impacts the reliability of the estimates of almost all forest ecosystem services including carbon sequestration. This is a rather unexpected result because the existing system is based on the principles of continuous forest inventory and should provide the annual estimation of all forest parameters. The difference between official forest inventory data $\left(9573.9 \times 10^{3} \mathrm{ha}\right)$ and the hybrid forest map $\left(8712.5 \pm 226.2 \times 10^{3} \mathrm{ha}\right)$ is large $(\sim 9 \%)$, and the spatial distribution shows an important feature, i.e., while regions of the forest zone and mountains have forest areas that are close to the inventory data, the areas in the regions of the southern forest steppe and steppe differ by up to $30 \%$ or more. This cannot be explained by the uncertainty from the remote sensing assessment. The resolution of the hybrid forest map is sufficiently fine such that substantial biases are avoided. The study also shows that the integration of relevant remote sensing products through advanced spatial analytical methods such as geographically weighted regression in combination with reference data collected through Geo-Wiki allows us to provide a forest cover map for a specific date with a satisfactory level of accuracy. The independent use of the flux- and stock-based methods of carbon accounting resulted in a rather low level of uncertainty, i.e., $\pm 3.6 \%$. This high level of accuracy has positive implications for acceptability by policy makers (Shvidenko et al. 2010).

There have been very few results published in the past for the entire country. These are limited to the official reporting of Ukraine to the Secretariat of the IPCC. The 6th National communication of Ukraine (http://unfccc.int/national_reports/items/1408.php) reported a net carbon sink of $161.6 \mathrm{~g} \mathrm{C} \mathrm{m}^{-2}$ year $^{-1}$ for the last few decades, which is about one fifth higher than the estimate found in this study $\left(135 \pm 38 \mathrm{~g} \mathrm{C} \mathrm{m}^{-2}\right.$ year $\left.^{-1}\right)$. The National Communications are based on data from the National Cadastre of anthropogenic emissions and removals, which is updated periodically (www.seia.gov.ua/seia/doccatalog/document?id=138881); for 2010, the net carbon sink was estimated at $146 \mathrm{~g} \mathrm{C} \mathrm{m}^{-2}$ year $^{-1}$. These results were based on the IPCC methodology, the official forest inventory data, and the assumption that the amount of carbon in the soil of forested areas has not changed over time. In a model-based approach for European countries, Schulze et al. (2010) estimated the average sink for Ukrainian forests to be $138 \mathrm{~g} \mathrm{C} \mathrm{m}^{-2}$ year $^{-1}$, which is $\sim 5.4 \%$ higher than the estimate produced in this study. Using the flux-based method, Shvidenko et al. (2014) estimated the sink to be $115 \pm 29$ $\mathrm{g} \mathrm{C} \mathrm{m}^{-2}$ year $^{-1}$ (or $12 \%$ lower than the result found in this study) using forest inventory data aggregated by administrative units. This study also reported the result of applying the stockbased method where the dynamics of LB and dead wood were assessed directly, and changes in soil carbon were based on the aggregation of available empirical data. The estimate was 108 $\mathrm{g} \mathrm{C} \mathrm{m}^{-2}$ year $^{-1}$, or about $17 \%$ lower than the carbon sink estimated by the stock-based method 
in this study. Overall, the reported results of the carbon sink per unit area vary, but in a relatively limited range.

The carbon sink was recently assessed using a system-based approach for forests in 25 countries of the EU, resulting in $75 \pm 25 \mathrm{~g} \mathrm{C} \mathrm{m}^{-2}$ year $^{-1}$ and an NBP to NPP ratio of 0.15 (Luyssaert et al. 2010). This is substantially less than our estimates for Ukraine (131 $\mathrm{g} \mathrm{C} \mathrm{m}^{-2}$ year $^{-1}$ and 0.21 , respectively). However, it is necessary to note that Ukraine has about $50 \%$ of protected forests with a very limited regime of wood harvesting. In addition, we used official data for the assessment of the amount of harvested wood. These data are biased because they do not take into account illegal harvesting in Ukraine, which is substantial, i.e., up to 1.0-1.2 $\mathrm{M} \mathrm{m}^{3}$ year $^{-1}$ (Kiiko 2009; Kuemmerle et al. 2009). Note that in order to exclude the impact of differences in the forest area, we compared the average values of the carbon sink. The differences between the estimates of the total carbon sink for the entire country are clearly higher and could reach up to $20-25 \%$ due to the differences in forest area. Hence, the above comparisons include some inconsistencies because different studies have used different methods and different information and were sometimes related to different time periods.

Only one of the above cited studies for Ukraine attempted to assess the uncertainty in the intermediate and final results, which were lower than those reported in this study (Shvidenko et al. 2014). However, this study assumed that the forest inventory presents accurate data about the area of forests in Ukraine. As we have shown here, this does not correspond to reality. The 2010 forest map produced here clearly indicates a lower forest area in Ukraine, particularly in critical growing conditions. This process can relate to both ongoing climate change and decreases in forest governance due to the complicated political situation in the country and military operations in the southeast. Thus, more research is required for providing more accurate estimates of this critical process of change.

Note that the uncertainties in the carbon budget assessment of this study should be used with some caveats. First, the calculation schemes of uncertainty assume that all initial data, empirical aggregations, and semi-empirical models that are used do not have statistically significant biases. To a significant extent, this seems true with respect to the models and the calculation schemes used, the adequacy of which has been controlled by statistical analysis. However, such a statement with respect to the initial data from the forest inventory may be an oversimplification in several important cases, e.g., connected to unknown uncertainties of forest inventory data. Secondly, all considerations of uncertainties are based on normal distributions. An analysis of the major inputs and the calculated intermediate and final results shows that the majority of distributions are similar to a normal (mostly Gram-Charlier) distribution. Hence, this assumption will not have a significant impact on the conclusions. Thirdly, different methods define different indicators, e.g., the flux-based method produces NBP, while the stock-based approach produces the NECB. Fourth, some of the calculations are based on the forest inventory, which is missing around $9 \%$ of Ukrainian forests. Covering this gap through analogs will introduce some unknown errors, but these should be relatively small. Finally, all the calculations include the limited use of expert estimates for practical reasons, which introduces some subjectivity into the analysis.

It is important to understand that a full carbon account of forest ecosystems is an ill-defined and hence fuzzy problem whose membership functions are inherently stochastic. This means that the uncertainty arising from any individual method of studying the carbon cycle is inevitably incomplete because it does not contain structural uncertainty, which could be significant. Any judgment about either total uncertainty or the "uncertainty of uncertainties" 
requires additional information that can only be provided by independent results obtained from other methods (Shvidenko et al. 2010, 2015). Carbon accounting by other methods (such as landscape and global vegetation models, eddy covariance, and direct assessment of carbon cycle parameters by remote sensing) has either not been undertaken in Ukraine, or the spatial resolution of the global products has been too coarse for the reliable assessment of uncertainties in the past. However, the above results from recent inventory studies do present some indirect evidence for judging the full uncertainties of the account.

This study has policy and forest management applications. It demonstrates that even in countries with a rather well-organized forest inventory such as Ukraine, official statistics may be partially obsolete and biased. As shown in recent studies, the national forest information reported to FAO's Forest Resource Assessment is very uncertain for many countries (Schepaschenko et al. 2015), and novel methodologies, which are based on remote sensing within an applied systems analysis approach, open up new ways for substantial improvements in international reporting quality. At a national level, Ukraine requires the development of a modern system of forest accounting, which would aggregate national and management forest inventories, as well as forest monitoring, in a systems approach. State ownership of forests in the country would promote the development of such a system. Moreover, the increasing role of science in studying forest ecosystem services is urgently needed. For example, there are no eddy covariance measurements in Ukrainian forests, and remote sensing data are not used in the forest inventory in any systems approach.

The methods of carbon accounting used here are limited by an understanding of the processes occurring within forest ecosystems. Hence future research should include two important components in the account. One is the protective role of forests outside of forest areas, particularly in agroforestry landscapes, their impacts on the productivity of agricultural land, and the protection of soil and water. Second is a consideration of the impacts of technological chains of forest products from forests to end users and the impacts of these on emissions and removals of greenhouse gases.

Climate change generates substantial risks and challenges for Ukrainian forests. As has been shown in previous research, the vulnerability of Ukrainian forests to climate change is high even under moderate IPCC scenarios such as A1B (Shvidenko et al. 2017). According to this study, the central and southern regions of the country will face untenable conditions for the growth of forests by the end of this century with clearly negative consequences for the carbon budget of forest ecosystems. This would require substantial national efforts and strategies for the adaptation of forest ecosystems to climate change as well as mitigation efforts to tackle the undesirable consequences (Vasilchenko et al. 1998; Buksha and Pasternak 2005; Nijnik 2005; Shvidenko et al. 2017).

\section{Conclusions}

For countries that do not currently have land cover data with an accuracy of higher than $85 \%$, e.g., Eastern European countries such as Russia, Belarus, and Moldova, the hybrid mapping methodology presented here provides an opportunity to develop forest maps that can be used in different national, regional, and global applications, including spatial-temporal accounting and verification of emissions and removals of greenhouse gases. This study shows that the application of advanced systems analyses to difficult and ill-defined tasks can result in outputs that are accurate enough to be used for policy implementation and forest management. The use 
of spatially explicit products such as those developed here minimizes the impacts of one of the most uncertain components of the carbon accounting of forest ecosystems, i.e., the lack of operational knowledge about spatial-temporal changes in forests, which is not satisfactorily reflected in the forest inventories of many countries.

However, with respect to further improvements in advanced methodologies for understanding the carbon cycle of forest ecosystems, this study presents an initial step forward in the development of a multi-sensor remote sensing approach. At the same time, this study highlighted information gaps in different areas, e.g., in understanding biogeochemical processes (particularly below ground) or in forest inventories. The study also underlined the need for better system consistency across all types of information inputs. Only a comprehensive integration of ground and remote sensing methods is able to satisfactorily cover the major requirements of a full and verified carbon accounting system. Further improvements in applications of remote sensing methods should deal with the estimation of the biophysical indicators of forest ecosystems, which are not defined satisfactorily (or are not currently defined at all) by current forest inventories. Among these, indicators of the vulnerability of forest ecosystems and the stability of forest landscapes are those of principal importance for the development of prospective national forest information systems in a world that is subject to ongoing environmental change.

Acknowledgements Open access funding provided by International Institute for Applied Systems Analysis (IIASA).

Funding information The work was supported by Marie Curie grant FP7-MC-IIF: SIFCAS Project No. 627481 and OeAD project UA 08/2017.

Open Access This article is distributed under the terms of the Creative Commons Attribution 4.0 International License (http://creativecommons.org/licenses/by/4.0/), which permits unrestricted use, distribution, and reproduction in any medium, provided you give appropriate credit to the original author(s) and the source, provide a link to the Creative Commons license, and indicate if changes were made.

\section{References}

Bilous A, Myroniuk V, Holiaka D et al (2017) Mapping growing stock volume and forest live biomass: a case study of the Polissya region of Ukraine. Environ Res Lett 12:105001

Bontemps S, Defourny P, van Bogaert E, et al (2011) GLOBCOVER 2009: Products Description and Validation Report

Brus DJ, Hengeveld GM, Walvoort DJJ, Goedhart PW, Heidema AH, Nabuurs GJ, Gunia K (2012) Statistical mapping of tree species over Europe. Eur J For Res 131:145-157. https://doi.org/10.1007/s10342-011-0513-5

Buksha IF, Butrim OV, Pasternak VP (2008) Inventory of greenhouse gases in sector of LULUCF. National Agrarian University, Kharkiv

Buksha IF, Pasternak VP (2005) Iventory and monitoring of greenhouse gases in forestsry. National Agrarian University, Kharkiv

Bun R, Gusti M, Dachuk V (2004) Information technologies of greenhouse gases inventory and forecast of carbon balance of Ukraine. Ukrainian Academy of Priting, Lviv

Chen J, Ban Y, Li S (2014) China: open access to earth land-cover map. Nature 514:434-434

DiMiceli CM, Carroll ML, Sohlberg RA, et al (2011) Annual Global Automated MODIS Vegetation Continuous Fields (MOD44B) at $250 \mathrm{~m}$ Spatial Resolution for Data Years Beginning Day 65, 2000-2010, Collection 5 Percent Tree Cover

Dolman AJ, Shvidenko A, Schepaschenko D, Ciais P, Tchebakova N, Chen T, van der Molen MK, Belelli Marchesini L, Maximov TC, Maksyutov S, Schulze ED (2012) An estimate of the terrestrial carbon budget of Russia using inventory-based, eddy covariance and inversion methods. Biogeosciences 9:5323-5340 
Foody GM (2004) Thematic map comparison: evaluating the statistical significance of differences in classification accuracy. Photogramm Eng Remote Sens 70:627-633

Fourdichko OI, Gladun GB, Lavrov VV (2006) Forest in steppe: background of sustainable development. Osnova publ, Kiev

Fritz S, McCallum I, Schill C, Perger C, See L, Schepaschenko D, van der Velde M, Kraxner F, Obersteiner M (2012) Geo-Wiki: an online platform for improving global land cover. Environ Model Softw 31:110-123. https://doi.org/10.1016/j.envsoft.2011.11.015

Gallaun H, Zanchi G, Nabuurs GJ, Hengeveld G, Schardt M, Verkerk PJ (2010) EU-wide maps of growing stock and above-ground biomass in forests based on remote sensing and field measurements. For Ecol Manag 260:252-261

Galos B, Hansler A, Kinderman G et al (2013) The role of forests in mitigating climate change - a case study for Europe. Acta Silv Lignaria Hung 8:87-102. https://doi.org/10.2478/v10303-012-0007-2

Hansen MC, Potapov PV, Moore R, Hancher M, Turubanova SA, Tyukavina A, Thau D, Stehman SV, Goetz SJ, Loveland TR, Kommareddy A, Egorov A, Chini L, Justice CO, Townshend JRG (2013) High-resolution global maps of 21 st-century forest cover change. Science 342:850-853. https://doi.org/10.1126 /science. 1244693

Kiiko OA (2009) Propect of development of production of slabby woody materials in Ukraine. Scientific Gerald of the National Forest Technical University of Ukraine 156-163

Kramer K, Mohren GMJ (2001) Long term effects of climate change on carbon budget of forests in Europe. Wagenningen. Alterra, Green World Research, Wageningen, the Netherlands

Krupsky NK, Polupan NI (1979) Atlas of soils of the Ukrainian SSR, Kiev, Urozhay, 160 p. Urozhay

Kuemmerle T, Chaskovskyy O, Knorn J, Radeloff VC, Kruhlov I, Keeton WS, Hostert P (2009) Forest cover change and illegal logging in the Ukrainian Carpathians in the transition period from 1988 to 2007. Remote Sens Environ 113:1194-1207. https://doi.org/10.1016/j.rse.2009.02.006

Kuemmerle T, Olofsson P, CHASKOVSKYY O et al (2011) Post-Soviet farmland abandonment, forest recovery, and carbon sequestration in western Ukraine. Glob Change Biol 17:1335-1349. https://oi.org/10.1111 /j.1365-2486.2010.02333.x

Kutsch WL, Persson T, Schrumpf M, Moyano FE, Mund M, Andersson S, Schulze ED (2010) Heterotrophic soil respiration and soil carbon dynamics in the deciduous Hainich forest obtained by three approaches. Biogeochemistry 100:167-183. https://doi.org/10.1007/s10533-010-9414-9

Le Quéré C, Andrew RM, Friedlingstein P et al (2017) Global carbon budget 2017. Earth Syst Sci Data Discuss 2017:1-79. https://doi.org/10.5194/essd-2017-123

Lesiv M, Moltchanova E, Schepaschenko D, See L, Shvidenko A, Comber A, Fritz S (2016) Comparison of data fusion methods using crowdsourced data in creating a hybrid forest cover map. Remote Sens 8 . https:/doi. org/10.3390/rs8030261

Liski J, Perruchoud D, Karjalainen T (2002) Increasing carbon stocks in the forest soils of western Europe. For Ecol Manag 169:159-175. https://doi.org/10.1016/S0378-1127(02)00306-7

Luyssaert S, Ciais P, Piao SL et al (2010) The European carbon balance. Part 3: forests. Glob Change Biol 16: $1429-1450$

Metsaranta JM, Shaw CH, Kurz WA, Boisvenue C, Morken S (2017) Uncertainty of inventory-based estimates of the carbon dynamics of Canada's managed forest (1990-2014). Can J For Res 47:1082-1094. https://doi. org/10.1139/cjfr-2017-0088

Mukhortova L, Schepaschenko D, Shvidenko A, McCallum I, Kraxner F (2015) Soil contribution to carbon budget of Russian forests. Agric For Meteorol 200:97-108. https://doi.org/10.1016/j.agrformet.2014.09.017

Mund V, Schulze E-D (2006) Impacts of forest management on the carbon budget of European beech (Fagus sylvatica) forests. Allgemeine Forst- and Jag- Zeitung 47-63

Nabuurs G-J, Schelhaas M-J, Mohren G (f) MJ, Field CB (2003) Temporal evolution of the European forest sector carbon sink from 1950 to 1999. Glob Change Biol 9:152-160. https://doi.org/10.1046/j.1365-2486.2003.00570.x

Nijnik M (2005) Economics of climate change mitigation forest policy scenarios for Ukraine. Clim Policy 4:319336. https://doi.org/10.3763/cpol.2004.0424

Olofsson P, Foody GM, Herold M, Stehman SV, Woodcock CE, Wulder MA (2014) Good practices for estimating area and assessing accuracy of land change. Remote Sens Environ 148:42-57. https://oi. org/10.1016/j.rse.2014.02.015

Pampel FC (2000) Logistic regression: a primer. SAGE, Thousands Oaks

Pan Y, Birdsey RA, Fang J, Houghton R, Kauppi PE, Kurz WA, Phillips OL, Shvidenko A, Lewis SL, Canadell JG, Ciais P, Jackson RB, Pacala SW, McGuire AD, Piao S, Rautiainen A, Sitch S, Hayes D (2011) A large and persistent carbon sink in the World's forests. Science 333:988-993. https://doi.org/10.1126/science.1201609

Pasternak VP (2011) Bioproductivity of forests of Northern East of Ukraine, Kiev, National University of Life Sciences. National University of Life Sciences, Kiev

Schepaschenko D, Fritz S, See L, Laso Bayas JC, Lesiv M, Kraxner F, Obersteiner M (2017a) Comment on "the extent of forest in dryland biomes". Science 358:eaao0166. https://doi.org/10.1126/science.aao0166 
Schepaschenko D, McCallum I, Shvidenko A, Fritz S, Kraxner F, Obersteiner M (2011) A new hybrid land cover dataset for Russia: a methodology for integrating statistics, remote sensing and in-situ information. J Land Use Sci 6(4):245-259. https://doi.org/10.1080/1747423X.2010.511681

Schepaschenko D, See L, Lesiv M, McCallum I, Fritz S, Salk C, Moltchanova E, Perger C, Shchepashchenko M, Shvidenko A, Kovalevskyi S, Gilitukha D, Albrecht F, Kraxner F, Bun A, Maksyutov S, Sokolov A, Dürauer M, Obersteiner M, Karminov V, Ontikov P (2015) Development of a global hybrid forest mask through the synergy of remote sensing, crowdsourcing and FAO statistics. Remote Sens Environ 162:208220. https://doi.org/10.1016/j.rse.2015.02.011

Schepaschenko D, See L, McCallum I et al (2012) Observing forest biomass globally. Earthzine

Schepaschenko D, Shvidenko A, Usoltsev V, Lakyda P, Luo Y, Vasylyshyn R, Lakyda I, Myklush Y, See L, McCallum I, Fritz S, Kraxner F, Obersteiner M (2017b) A dataset of forest biomass structure for Eurasia. Sci Data 4:170070. https://doi.org/10.1038/sdata.2017.70

Schierhorn F, Müller D, Beringer T, Prishchepov AV, Kuemmerle T, Balmann A (2013) Post-Soviet cropland abandonment and carbon sequestration in European Russia, Ukraine, and Belarus. Glob Biogeochem Cycles 27:1175-1185. https://doi.org/10.1002/2013GB004654

Schulze E-D, Ciais P, Luyssaert S, et al (2010) The European carbon balance. Part 4: integration of carbon and other trace-gas fluxes. Glob Change Biol 16. doi: https://doi.org/10.1111/j.1365-2486.2010.02215.x, 1451, 1469

Shimada M, Itoh T, Motooka T, Watanabe M, Shiraishi T, Thapa R, Lucas R (2014) New global forest/non-forest maps from ALOS PALSAR data (2007-2010). Remote Sens Environ 155:13-31. https://doi.org/10.1016/j. rse.2014.04.014

Shvidenko A, Buksha I, Krakovska S, Lakyda P (2017) Vulnerability of Ukrainian forests to climate change. Sustainability 9. doi: https://doi.org/10.3390/su9071152

Shvidenko A, Lakyda P, Schepaschenko D (2014) Carbon, climate and land-use in Ukraine: forest sector. IIASA and National University of life sciences and environment of Ukraine. Kiev, Ukraine

Shvidenko A, Schepaschenko D, Kraxner F, Fritz S (2015) Full verified carbon account of forest ecosystems as a fuzzy system: an attempt to assess uncertainty. In: Proceedings of the 4th international workshop on uncertainties in atmospheric emissions. Systems Research Institute, Polish Academy of Sciences, Krakow, Poland, pp 1-8

Shvidenko A, Schepaschenko D, McCallum I, Nilsson S (2010) Can the uncertainty of full carbon accounting of forest ecosystems be made acceptable to policymakers? Clim Chang 103:137-157

Shvidenko A, Schepaschenko D, Nilsson S, Bouloui Y (2007) Semi-empirical models for assessing biological productivity of northern Eurasian forests. Ecol Model 204:163-179

Smaliychuk A, Müller D, Prishchepov AV, Levers C, Kruhlov I, Kuemmerle T (2016) Recultivation of abandoned agricultural lands in Ukraine: patterns and drivers. Glob Environ Change 38:70-81. https://doi. org/10.1016/j.gloenvcha.2016.02.009

Ukrstateforestproject (ed) (2012) Book on Forest Fund of Ukraine (state at 01.01.2011), 1st edn. Ukrstateforestproject. Irpen, Ukraine

Ustsky IM (2011) Dynamics of state of forests of major forest forming species of Ukraine in 1990-2006. Ukrainian Forest Hunt 1:32-35

Ustsky IM, Taran TV, Bilous VP (2010) Complex estimation of expansion of forest pathological processes (differenciated by administrative regios of Ukraine) and their forecast in Ukrainian forests by 2015. State Commitee of Forest Management of Ukraine and National Academy of sciences of Ukraine, Kyiv

Vasilchenko VV, Raptsun MV, Trofimova IV (1998) Vulnerability and adaptation of ecological and economic systems to climate change. Agency of Effective Use of Energy and Ecology, Kiev

Werner M (2001) Shuttle radar topography mission (SRTM) mission overview. J Telecom (Frequenz) 55:75-79

Wulder MA, Masek JG, Cohen WB, Loveland TR, Woodcock CE (2012) Opening the archive: how free data has enabled the science and monitoring promise of Landsat. Remote Sens Environ 122:2-10. https://oi. org/10.1016/j.rse.2012.01.010 